\title{
SHOULDER ARTHRODESIS USING AN EXTERNAL FIXATOR
}

\author{
ANDRZEJ KOCIALKOWSKI, W. A. WALLACE
}

The major problem with arthrodesis of the shoulder has been a high incidence of nonunion and the need for prolonged external splintage. The development of internal fixation with the dynamic compression plate has resulted in a union rate of $100 \%$ (Kostuik and Schatzker 1984). However, patients who are thin have poor subcutaneous tissue and are not good candidates for this method of treatment because of the possibility of erosion of the metal through the thin tissues. In order to avoid the use of a shoulder spica for three months, we have, in selected cases, used the Hoffmann external fixator as described by Nielsen (1986) combined with internal fixation with two $6.5 \mathrm{~mm}$ cancellous screws.

Case 1. A 33-year-old man had a history of bilateral recurrent posterior dislocation of his shoulders. He was treated initially by posterior bone block stabilisations bilaterally and later by glenoid osteotomy and posterior capsular plication. Following a further injury, the left shoulder became grossly unstable. As soft-tissue surgery had failed on two occasions, an arthrodesis was performed. Through a posterior approach the humeral articular surface was removed and flattened for glenoid surface contact and curved for acromion surface contact. One screw was passed through the acromion vertically into the humeral head and neck and one was inserted transversely across the humeral head into the glenoid, which was roughened to cancellous bone. The joint was held in $30^{\circ}$ flexion, $30^{\circ}$ abduction and $30^{\circ}$ internal rotation. Additional stabilisation was provided by the Hoffman external fixator with three pins introduced into the scapular spine (the lateral pin also entering the humeral head), and three into the humeral shaft. Four months later the fixator was removed under sedation. One year after arthrodesis he has active combined flexion to $80^{\circ}$, can get his hand to his mouth, to the back of his neck and to his perineum.

A. Kocialkowski, Visiting Research Fellow at Queen's Medical Centre Department of Traumatic Surgery, Medical Academy of Poznan, Poland.

W. A. Wallace, FRCS Ed, FRCS Ed(Orth)

Department of Orthopaedic and Accident Surgery, University of Nottingham, Queen's Medical Centre, Nottingham NG7 2UH, England.

Correspondence to Professor W. A. Wallace.

(C) 1991 British Editorial Society of Bone and Joint Surgery 0301-620X/91/1R98 \$2.00

J Bone Joint Surg [Br] 1991; 73-B:180-1.

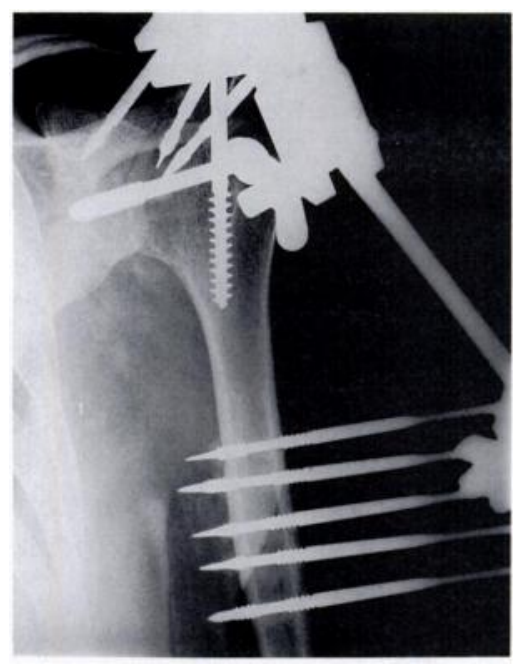

Fig. 1

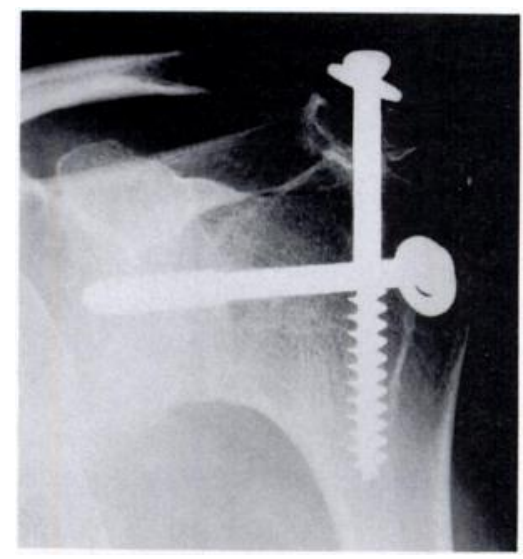

Fig. 2

Case 2. A 70-year-old woman was referred with a complete right rotator cuff tear; repair was inappropriate because she had fits and falls and re-injury was likely. In order to relieve her severe pain an arthrodesis was performed. A year later she has no pain, arm elevation is to $60^{\circ}$ and she is able to get her hand to her mouth and to her neck.

Case 3. A 45-year-old man had a history of poliomyelitis at the age of two affecting his left shoulder muscles. He had wasting and muscle weakness of the left upper limb and developed recurrent inferior and anterior subluxation of the shoulder. As he had no muscles to move his 
shoulder, an arthrodesis was performed (Fig. 1). Two years later the fusion is solid (Fig. 2) with active elevation to $70^{\circ}$ and the ability to reach his mouth, the back of his neck and the lower lumbar spine.

Case 4. A 59-year-old man sustained a fracture dislocation of the right shoulder with a brachial plexus injury 12 years previously. As he complained of constant severe pain and had an extremely weak rotator cuff, an arthrodesis was performed. A year later he has no pain, the fusion is solid and he has combined elevation of his arm to $70^{\circ}$.

Discussion. Several techniques had been described which combine intra- and extra-articular arthrodesis. Charnley and Houston in 1964 reported their method of compression clamps and a shoulder spica. The difficulty of producing a solid shoulder fusion results from the small area of contact between the scapula and the humerus and the problem of immobilising the scapula. The crucial points for success seem to be an appropriate reshaping of the humeral head and firm immobilisation of the scapulohumeral complex in the optimal position for the arm. We recommend the combined external and internal fixation technique which is not difficult, obviates the need for long periods of plaster and provides good stabilisation of the joint.

No benefits in any form have been received or will be received from a commercial party related directly or indirectly to the subject of this article.

\section{REFERENCES}

Charnley J, Houston JK. Compression arthrodesis of the shoulder. $J$ Bone Joint Surg [ Br] 1964; 46-B :614-20.

Kostuik JP, Schatzker J. Shoulder arthrodesis - A.O. technique. In : Bateman JE, Welsh RP, eds. Surgery of the shoulder. St. Louis, etc CV Mosby Co, 1984:207-10.

Nielsen HKL. Shoulder arthrodesis with the aid of external fixation. In : Takagishi N. ed. The Shoulder. Procs of the 3rd International Conference on Surgery of the Shoulder, Japan, 1986. US, etc Professional Postgraduate Services 1987:377-80.

\section{CORRECTION}

Alho A, Ekeland A, Strømsøe K, Follerås G, Thoresen BO. Locked intramedullary nailing for displaced tibial shaft fractures.

J Bone Joint Surg [Br] 1990; 72-B :805-9.

On page 806 , the first sentence of the second paragraph should read:

"We performed 47 of the operations within 24 hours, 19 within the first week and 27 later, but less than two months after fracture." 